\title{
Effects of rearing practice on post-release young-of-the-year behavior: Acipenser sturio early life in freshwater
}

\author{
Erika Carrera-García ${ }^{1,2, *}$, Eric Rochard ${ }^{1}$, Marie-Laure Acolas ${ }^{1}$ \\ ${ }^{1}$ IRSTEA, National Research Institute of Science and Technology for Environment and Agriculture, EABX, \\ Aquatic Ecosystems and Global Changes Research Unit, 33612 Bordeaux, France \\ ${ }^{2}$ Department of Biological Sciences, Pontificia Universidad Católica del Ecuador, 131103 Bahía de Caráquez, Ecuador
}

\begin{abstract}
Stocking is becoming an increasingly important conservation tool as biodiversity trends continue to decline. The European sturgeon Acipenser sturio is a Critically Endangered species subject to a stocking program in which a better understanding of its life history and stocking achievement is crucial for its conservation. In this study, acoustic telemetry assessment of postrelease behavior of 3 mo old fish was carried out for the first time on a sturgeon species. We aimed to improve the knowledge of movement, distribution and survival of the species' freshwater early juveniles within the context of stocking practices. Fish belonging to 2 half-sib families were reared in enriched and traditional hatchery conditions, tagged and monitored for $21 \mathrm{~d}$ in the Dordogne River, France. Fish overall survival proxy was $69.3 \%$ (52.2 to $90.9 \%)$; the lowest survival was found for 1 family reared traditionally. After release, most movements $(85.7 \%)$ occurred during the first $3 \mathrm{~d}$ after stocking and were oriented in a downstream direction. Over the course of the study, $82 \%$ of fish were detected within $13.5 \mathrm{~km}$ of the release site. No differences in total distance covered $(7.5 \pm 7.0 \mathrm{~km})$ were found between treatments. Three enriched-reared fish reached the tidal area (26 to $32 \mathrm{~km}$ from the release site) but none reached the saline zone of the estuary. Fish were mainly active at night, but traditionally-reared fish were significantly more active during the day than enriched-reared fish during the first $3 \mathrm{~d}$. The study provides the first insights into early life in freshwater for this species; this knowledge will help improve stocking practices.
\end{abstract}

KEY WORDS: Acoustic telemetry $\cdot$ Stocking $\cdot$ Behavior $\cdot$ Sturgeon $\cdot$ Rearing condition

\section{INTRODUCTION}

The world's biodiversity is declining and the most impacted habitats are freshwater environments (Dudgeon et al. 2006). To overcome this loss of diversity, a wide range of actions have been taken worldwide; fish species have benefited from specific conservation measures such as habitat protection and restoration, fishing regulations and specific targeted stocking practices (Waldman \& Wirgin 1998, Arlati \& Poliakova 2009, Williot et al. 2009).

Stocking is considered an important tool for conservation that is gaining relevance as biodiversity trends

${ }^{*}$ Corresponding author: erikacarreragarcia@gmail.com continue to decline (Reading et al. 2013). In stocking, the released individuals are often captive-born. This highlights the importance that aquaculture has in species conservation, as the survival of early stages can be significantly higher than survival of these stages in the wild (Secor et al. 2002). But there are major concerns regarding the quality of fish as a consequence of selective reproduction (Campton 1995, Zhu et al. 2002, Yokota et al. 2003, Susnik et al. 2004, Jager 2005) and early life experiences in artificial environments (Braithwaite \& Salvanes 2005, Salvanes \& Braithwaite 2006, Johnsson et al. 2014) that may not produce fish well-suited to face life in the wild. Sev-

(C) The authors 2017. Open Access under Creative Commons by Attribution Licence. Use, distribution and reproduction are unrestricted. Authors and original publication must be credited. 
eral studies have suggested that enriched conditions, i.e. increasing habitat complexity, could be considered as a 'training' approach that would ease adjustment and increase survival after stocking (Braithwaite \& Salvanes 2005, Johnsson et al. 2014).

The European sturgeon Acipenser sturio is a Critically Endangered species (IUCN 2015) subject to a stocking conservation program. All but one of this species' populations have gone extinct during the last century (Lassalle et al. 2011). This means that scarce retrospective information is available on traits of their natural life history that are indispensable for their population conservation (Acolas et al. 2011b). As such, monitoring stocked populations is the only means to obtain such data while the stocking programs progress (Nichols \& Armstrong 2012, Gitzen et al. 2016).

The European sturgeon is an anadromous species: it reproduces in rivers, and juveniles migrate to estuaries in their first year of life. They remain and grow in estuaries for several years until they migrate to the sea, where they continue to grow, before coming back to the river to breed (Castelnaud et al. 1991, Acolas et al. 2011a). Most current knowledge on this species relates to their estuarine life phase (Rochard et al. 2001, Brosse 2003); the freshwater stage during their first year of life is poorly known (Acolas et al. 2011b).

Telemetry techniques are one of the most common and reliable approaches to obtain such data through an individual-based analysis of movements (Lucas \& Baras 2000, Cooke et al. 2004, Bégout et al. 2016). However, until now this technique has been used to monitor post-release survival (Parkyn et al. 2006, Rudd et al. 2014, Eder et al. 2015), habitat use (Jordan et al. 2006, Acolas et al. 2017), dispersal and migration (Secor et al. 2000, Neufeld \& Rust 2009) of stocked populations, and has been employed mainly on large juveniles. Due to transmitter design, the smallest sturgeons acoustically tracked in the wild were 9 mo old A. sturio (Acolas et al. 2012). Recently, a telemetry system (Juvenile Salmon Acoustic Telemetry System [JSATS]; Lotek ${ }^{\circledR}$ ) that was initially developed to acoustically track young salmon species (McMichael et al. 2010) has allowed the use of miniature tags on 3 mo old sturgeons (Carrera-García et al. 2017).

In our study, post-release behavior and survival assessment of 3 mo old individuals was carried out for the first time on a sturgeon species. We aimed to improve the understanding of movement, distribution and survival on the species' freshwater early juveniles within the context of stocking practices. Therefore, we assessed the effects of 2 rearing con- ditions on post-release behavior and survival of juveniles belonging to 2 different families. This specific life stage was chosen because it is one of the preferred stages used for stocking in the Gironde-Garonne-Dordogne basin, France (MEDDTL 2011).

\section{MATERIALS AND METHODS}

\section{Study area}

This study was carried out in a $73 \mathrm{~km}$ section of the Dordogne River, southwest France, between 29 September and 20 October 2014 (Fig. 1). The river is influenced by the tide, with an upstream tidal limit $162.5 \mathrm{~km}$ from the sea. In this solely freshwater area, the tide influences water depth and flow, but not salinity. The fish were released in Le Fleix, a nontidal river zone, which is a known historical spawning site (Jego et al. 2002). The surveyed section comprised $46 \mathrm{~km}$ in the tidal and $27 \mathrm{~km}$ in the non-tidal influence area with a depth ranging between 1 and $6.2 \mathrm{~m}$. During the study, mean $( \pm \mathrm{SD})$ river discharge was $106.2 \pm 19.4 \mathrm{~m}^{3} \mathrm{~s}^{-1}$ (HYDRO 2015). Temperature was recorded 3 times min $^{-1}$ using dataloggers (Tiny$\left.\operatorname{tag}^{\circledR}\right)$ placed in gates 5 and 9 of the studied river section (Fig. 1). The registered temperature was $17.88 \pm$ $0.55^{\circ} \mathrm{C}$, and was similar in both gates (Mann-Whitney [MW] $U=992108, \mathrm{p}=0.05$ ). Additionally, every $30 \mathrm{~min}$, a multi-parameter water quality probe (YSI $6600 \mathrm{~V} 2)$ located at the release site monitored oxygen $\left(9.05 \pm 0.55 \mathrm{mg} \mathrm{l}^{-1}\right), \mathrm{pH}(7.73 \pm 0.25)$ and conductivity $\left(173.61 \pm 136.75 \mu \mathrm{S} \mathrm{cm}^{-1}\right)$.

\section{Fish origin and rearing}

Fish originated from assisted fecundation of a single female with 2 males which constituted 2 half-sib families ( $\mathrm{C} 1=$ half-sib male $1, \mathrm{C} 2=$ half-sib male 2$)$, all wild-born spawners from the French captive stock (Williot et al. 2005). Fish were reared in captivity until 92 d post-hatch (dph; 3 mo old) using 2 rearing methods: enriched and traditional (Carrera-García et al. 2016). Traditional rearing was based on the protocol used to raise fish for stocking in the Gironde and captive stock supplementation (Chèvre et al. 2011). This method consisted of rearing fish in bare tanks with a flow-through system of underground water, in darkness with no current. Enriched rearing consisted of small mesocosms that imitated the natural environment: tanks were located outdoors with a flow- 


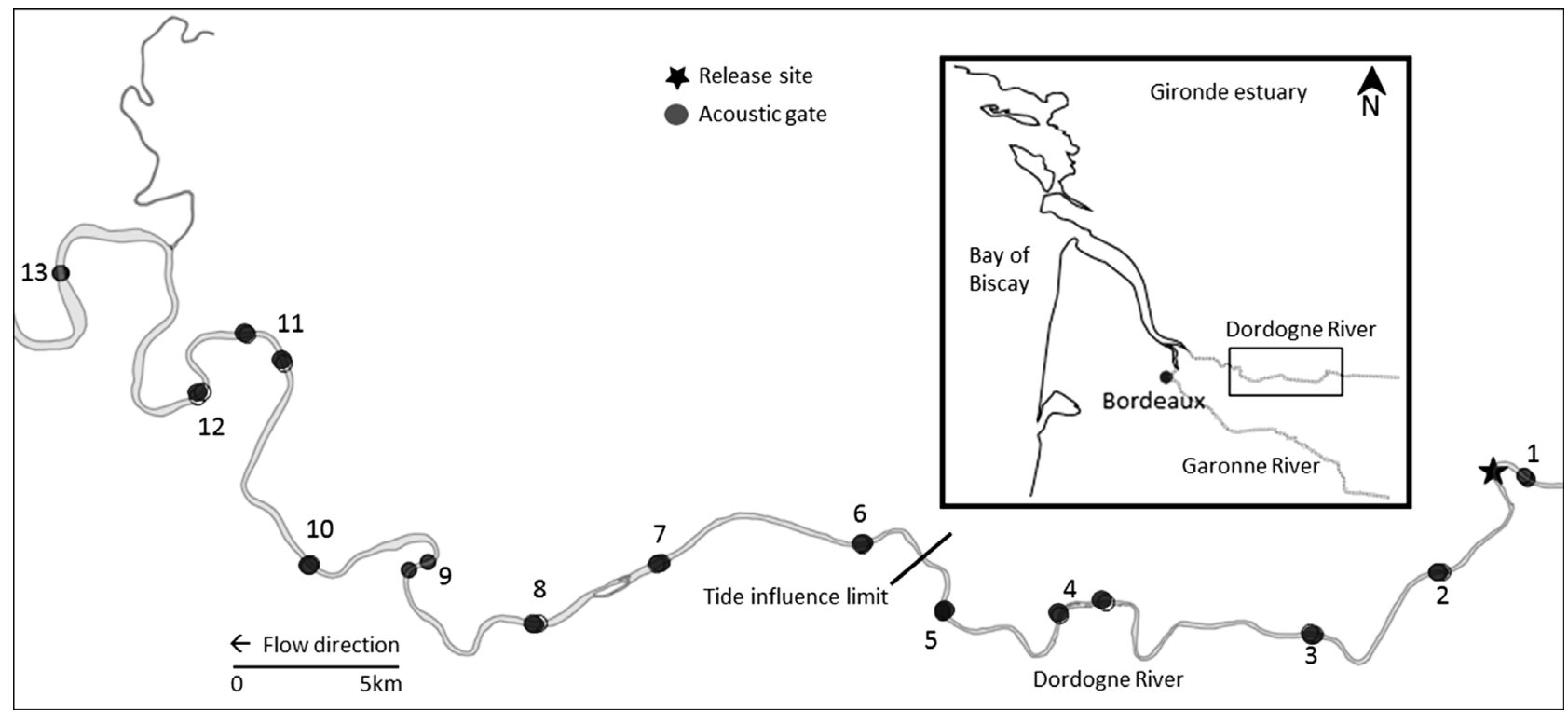

Fig. 1. Study area in the Dordogne River, southwest France. Star: stocking location of 3 mo old European sturgeons; circles: acoustic gates, each consisting of 2 receivers

through system of river water subject to natural photoperiod and temperature variations. This rearing condition also had variable water depth and current, and landscapes were created weekly using different substrates (Carrera-García et al. 2016). Fish in both rearing methods were fed ad libitum with live artemia Artemia salina beginning $9 \mathrm{dph}$ for $12 \mathrm{~d}$, followed by a mix of artemia and defrosted bloodworms Chironomus sp. for 9 more days and then only bloodworms as mentioned in Chèvre et al. (2011).
Table 1. Juvenile European sturgeon Acipenser sturio tagged before stocking in the Dordogne River, France. C1 and C2 indicate the fish family. For each line in the table, superscript letters indicate comparison between treatments: different letters represent significant differences at $p<0.05$

\begin{tabular}{|c|c|c|c|c|}
\hline \multirow{2}{*}{ Parameters } & \multicolumn{2}{|c|}{ Traditional rearing } & \multicolumn{2}{|c|}{ Enriched rearing } \\
\hline & C1 & $\mathrm{C} 2$ & $\mathrm{C} 1$ & $\mathrm{C} 2$ \\
\hline $\begin{array}{l}\text { Individuals tagged } \\
\text { and released }\end{array}$ & 23 & 21 & 22 & 22 \\
\hline $\begin{array}{l}\text { Individuals detected } \\
\text { in the wild }\end{array}$ & 12 & 14 & 20 & 15 \\
\hline Detection rate (\%) & 52.2 & 66.7 & 90.9 & 68.2 \\
\hline Weight (g) & $9.4 \pm 1.4^{\mathrm{a}}$ & $10.8 \pm 2.0^{\mathrm{b}}$ & $11.8 \pm 2.0^{\mathrm{b}}$ & $11.1 \pm 1.6^{\mathrm{b}}$ \\
\hline Total length (cm) & $13.4 \pm 0.7^{\mathrm{a}}$ & $14.0 \pm 0.8^{\mathrm{b}}$ & $14.8 \pm 0.8^{\mathrm{c}}$ & $14.4 \pm 0.6^{\mathrm{bc}}$ \\
\hline Tag burden $(\%)$ & $3.1 \pm 0.5^{\mathrm{a}}$ & $2.7 \pm 0.5^{\mathrm{b}}$ & $2.4 \pm 0.4^{\mathrm{b}}$ & $2.6 \pm 0.4^{\mathrm{b}}$ \\
\hline
\end{tabular}

\section{Fish tagging}

Acoustic transmitters (JSATS L-AMT-1.416 acoustic tags, Lotek $\left.{ }^{\circledR}\right)$ were surgically implanted into 88 fish (Table 1). Tags were $1.07 \times 0.54 \times 0.31 \mathrm{~cm}$ (length $\times$ width $\times$ thick), $0.28 \mathrm{~g}$ in air, with a delay rate of $5 \mathrm{~s}$. Fish were fasted for $24 \mathrm{~h}$ before surgery and sedation was performed using clove oil $\left(0.5 \mathrm{ml} \mathrm{l}^{-1}\right.$ of clove oil diluted in $5 \mathrm{ml}$ of ethanol per $10 \mathrm{l}$ of water). Following anesthesia, fish were measured for total length (TL) $(14.2 \pm 0.9 \mathrm{~cm}$; range: 12.0 to $16.3 \mathrm{~cm})$ and weighed $(10.8 \pm 2.0 \mathrm{~g} ; 6.6$ to $15.1 \mathrm{~g})$ (Table 1$)$. Transmitters represented 1.9 to $4.2 \%$ of the tagged fish body mass (Table 1). They were implanted into the peritoneal cavity using surgical procedure as described in
Carrera-García et al. (2017) through an approx. 7 to $8 \mathrm{~mm}$ incision, slightly left of the ventral midline and anterior to the pelvic girdle. Incisions were closed with 2 surgeon's knots using absorbable monofilament (Ethicon ${ }^{\circledR}$, PDS $^{\mathrm{TM}}$ II 4-0). The fish were kept in captivity for 3 additional days for post-surgery recovery and to check that the stiches were healing properly. Most fish $(n=65)$ were released on 29 September 2014; the remaining fish $(n=23)$ were released on 30 September. These individuals needed additional stitches because the wound had popped open (stitches were intact but torn on one side of the wound), likely as a result of feeding. The proportion of these fish did not differ between treatments $\chi^{2}(3)$ $=2.91, \mathrm{p}=0.40$ ) and did not differ in survival proxy 
$\left.\chi^{2}(1)=0.31, p=0.58\right)$ or mobility (Mann-Whitney [MW] $U=345.5, \mathrm{p}=0.65$ ) compared with the fish released the day before.

\section{Telemetry survey}

A total of 26 receivers (JSATS WHS4000, Lotek ${ }^{\circledR}$ ) were placed along the $73 \mathrm{~km}$ river section (Fig. 1). Receivers were placed about $0.8 \mathrm{~m}$ above the river's bottom in homogenous areas to hang the material in a vertical position and to avoid shadow zones in tag detection. Preliminary detection tests were performed from a boat $3 \mathrm{wk}$ in advance of stocking, whereby an activated tag was gradually moved away from a receiver. Detections could be obtained at $200 \mathrm{~m}$ around the receivers, but satisfactory detection range was considered at $100 \mathrm{~m}$ (distance at which $79.4 \%$ of the theoretic transmissions [every $5 \mathrm{~s}$ ] were detected; detections also occurred every 10,15 and 20 s). Based on these test results, each acoustic gate consisted of 2 receivers arranged according to river width. When river width was $<100 \mathrm{~m}$, the receivers were located one behind the other along the river's longitudinal axis; when width was $>100 \mathrm{~m}$, receivers were located side by side transversally to allow the detection ranges to overlap. The mean width of the river in the studied area was $150.2 \mathrm{~m}$; maximum width did not exceed $300 \mathrm{~m}$. Additionally, the receivers were checked once every week to ensure their correct position and location, and were cleaned to prevent dragging by biofouling. Data were collected once per week on 4 gates $(1,5,9,13)$ to orientate the active tracking (Fig. 1). Active tracking was done from a boat twice a week with a hand-operated receiver in the river sections where fish were detected by the nearby gates. For each fish detected, its depth and the mid-column water flow were recorded. Each passive receiver and each fish localized in active tracking were geo-localized using a differential GPS (Magellan MobileMapper CX). Fish tracking lasted $21 \mathrm{~d}$ due to tag battery life duration.

\section{Data analysis}

After verification of parametric test assumptions, fish initial weight, length and tag burden were compared between treatments (2 rearing environments $x$ 2 families) using a 2-way analysis of variance (ANOVA). Differences between the number of fish detected and the number of fish released for each treatment were expressed as a percentage and used as a survival proxy, because the release conditions and tracking effort were similar for all treatments (same number of fish, same tracking period). A chisquared test of independence was used to compare this survival proxy between treatments. Logistic regressions were used to determine if survival proxy could be explained by fish weight or tag burden at release for each treatment. To compare the total number of detections per fish between treatments, a Kruskal-Wallis (KW) test was used.

To analyze movement data, a database was constructed including both passive $(99.8 \%)$ and active $(0.2 \%)$ tracking data. Our acoustic data, obtained with the JSATS technology (frequency $=416 \mathrm{KHz}$ ), contained a considerable amount of false detections. Thus, these data required post-treatment using a receiver interface application (WHS Host, Lotek ${ }^{\circledR}$ ) and R statistical software (R Core Team 2013). The WHS Host application filtered the detections by known fish identification codes and, using $\mathrm{R}$ software, we selected consecutive detections spaced at $5,10,15$ or $20 \mathrm{~s}$ which were considered 'true detections' according to the preliminary tests. The database then consisted of detections associated with a location (the geographical coordinates of either the passive hydrophones or the active trackers), date and time for each fish. The hydrographical distances between 2 consecutive locations and their orientation (upstream, downstream, lateral, no movement) were estimated using ArcGIS v.10.2 (ESRI 2013) and Anaqualand v.2.0 (Le Pichon et al. 2006) software as in Acolas et al. (2012). We considered 'no movement' as corresponding to 2 consecutive locations of the same individual within the detection range of one receiver. Also, fish trajectories were smoothed using an estimation of fish ground swimming speed (maximum set at $0.8 \mathrm{~m} \mathrm{~s}^{-1}$ ) between 2 consecutive locations as an approach to discern overestimated data, which mainly occurred in the case of 'lateral movements'. This involved individuals detected by 2 hydrophones at the same gate, at the same time or within seconds of each other, for which the hydrographical calculations estimated distances as if the fish had moved from one hydrophone location to the other. In this case, the 'lateral movement' identified was considered as 'no movement'. The ground swimming speed threshold $\left(0.8 \mathrm{~m} \mathrm{~s}^{-1}\right)$ was calculated using double the maximum speed that a 3 mo old sturgeon (average fish length of $14.2 \mathrm{~cm}$ in this study) can sustain according to a preliminary current speed test ( 2 body lengths $\mathrm{s}^{-1}$; P. Jatteau pers. comm.) and the average current velocity estimated during the study $\left(0.09 \mathrm{~m} \mathrm{~s}^{-1}\right)$. Day, night and 
twilight time were determined weekly using a sunlight phase web application (SunCalc; Agafonkin 2009) based on this study's date and location. Sunrise and sunset together were considered as twilight (i.e. 06:22 to 08:02 $\mathrm{h}$ and 19:40 to $21: 21 \mathrm{~h}$, respectively). Movement data were analyzed according to 2 time scales: during the whole study $(\mathrm{n}=21 \mathrm{~d})$ and during the first $3 \mathrm{~d}$ and remaining days separately. For each time scale, Scheirer-Ray-Hare and MW tests were used to compare total distance covered (i.e. the sum of the distances between consecutive locations for each fish) between treatments and within each diel cycle. Spearman correlation was used to test total distance moved by each fish and fish length for the whole study. Statistical analyses were performed using IBM SPSS statistics software (IBM Analytics 2013); p-values < 0.05 were considered significant.

\section{RESULTS}

\section{Fish initial condition}

Analysis revealed that fish belonging to family $\mathrm{C} 1$, reared in the traditional environment, were the smallest of all groups in initial weight (enriched: $F_{1,42}$ $=1.63, \mathrm{p}=0.20$; traditional: $F_{1,42}=7.27, \mathrm{p}=0.01$ ) and length at tagging (enriched: $F_{1,42}=3.32, \mathrm{p}=0.08$; traditional: $\left.F_{1,42}=7.80, \mathrm{p}<0.01\right)$ and had the highest tag burden (enriched: $F_{1,42}=1.33, \mathrm{p}=0.25$; traditional: $F_{1,42}=7.19, \mathrm{p}=0.01$ ) (Table 1) (Fig. 2).

\section{Survival estimates}

Fish overall survival proxy was $69.3 \%$ ( $\mathrm{n}=61 \mathrm{fish}$ detected). There were no differences between the enriched-reared families ( $\mathrm{C} 1=90.9 \%, \mathrm{C} 2=68.2 \%$ ) and traditionally-reared C2 $(66.7 \%)\left(\chi^{2}=4.33, \mathrm{p}=\right.$ 0.11 ), but the traditionally-reared $\mathrm{C} 1$ treatment was significantly lower than the other treatments $(52.2 \%)$ $\left(\chi^{2}=8.21, \mathrm{p}<0.01\right)$ (Table 1$)$. Survival probability was not explained by initial weight (logit regression, $\mathrm{p}>0.08$ ), length (logit regression, $\mathrm{p}>0.10$ ) or tag burden (logit regression, $p>0.09$ ) for any of the treatments.

\section{General distribution patterns}

The total number of detections ( $\mathrm{n}=28873$ ) was highly variable between individuals, ranging from

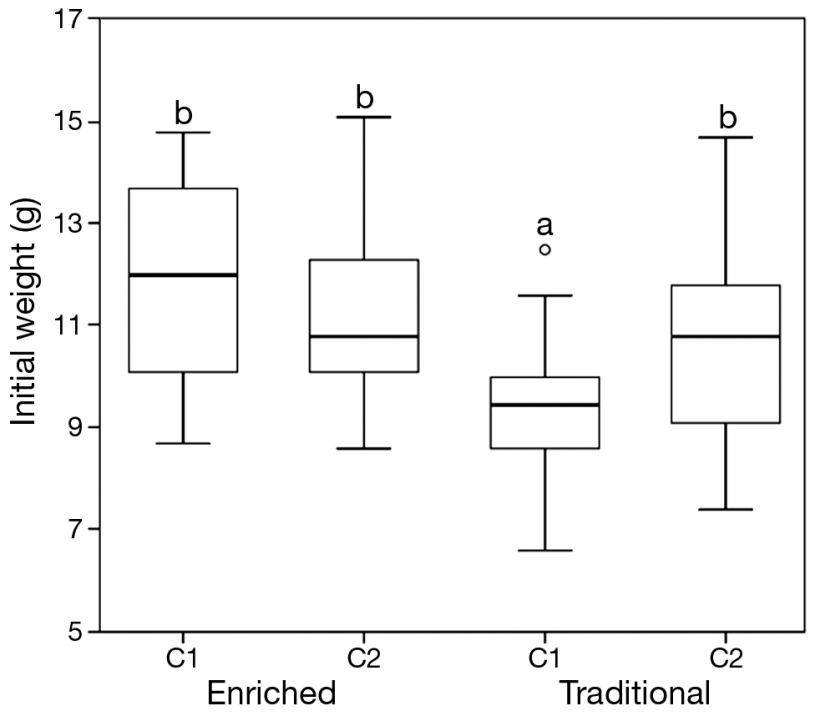

Fig. 2. Weight at tagging for 3 mo old European sturgeons belonging to 2 families ( $\mathrm{C} 1$ and $\mathrm{C} 2$ ), reared in enriched and traditional environments. Boxes: 1st and 3rd quartiles; line: median; whiskers: SD; circle: outlier. Different letters indicate significant differences at $\mathrm{p}<0.05$

2 to $25878(473.3 \pm 838.4)$; no differences between treatments were noticed $\left(\mathrm{KW}, H_{2}=3.03, \mathrm{p}=0.39\right)$. Over the course of the whole study, $82 \%$ of the fish ( $\mathrm{n}=50$; enriched: $\mathrm{C} 1=14, \mathrm{C} 2=14$; traditional: $\mathrm{C} 1$ $=12, \mathrm{C} 2=10$ ) were detected within the first $13.5 \mathrm{~km}$ (from the release site to halfway between acoustic gates 3 and 4 ), and no differences in proportions of fish between treatments were found $\left(\chi^{2}\right.$ $=6.94, \mathrm{p}=0.07)$. Moreover, among these fish, $30 \%$ ( $\mathrm{n}=15$; enriched: $\mathrm{C} 1=4, \mathrm{C} 2=2$; traditional: $\mathrm{C} 1=$ $5, \mathrm{C} 2=4$ ) settled within $1.2 \mathrm{~km}$ downstream of the release site. Of the remaining individuals, $13.1 \%$ (n $=8$; enriched: $\mathrm{C} 1=2, \mathrm{C} 2=2$; traditional: $\mathrm{C} 2=4$ ) moved downstream into the 13.5 to $26.5 \mathrm{~km}$ river section (halfway between gates 5 and 6) and only $4.9 \%$ ( $\mathrm{n}=3$; enriched $\mathrm{C} 1=3$ ) moved further than $26.5 \mathrm{~km}$ into the freshwater tidal area, but not beyond $32 \mathrm{~km}$ (halfway between gates 6 and 7 ). The 3 fish recorded in the freshwater tidal area were registered there $3 \mathrm{~d}$ after release. Most of the fish movements were downstream-oriented $(\mathrm{n}=60$, $7.88 \pm 7.02 \mathrm{~km})$, with few lateral $(\mathrm{n}=4,0.05 \pm 0.02$ $\mathrm{km}$ ) or upstream incursions $(\mathrm{n}=12,0.58 \pm 0.88$ $\mathrm{km}$ ); only 1 individual (enriched C1) was detected upstream of the stocking site $1 \mathrm{~d}$ after release. During active tracking alone, 35 fish were detected, 2 of which could not be located because of rapid signal attenuation (fish moving away). All remaining fish $(\mathrm{n}=33)$ were found in areas of $3.3 \pm 1.2 \mathrm{~m}$ depth and $0.09 \pm 0.09 \mathrm{~m} \mathrm{~s}^{-1}$ current velocity. 


\section{Movement characterization}

Whole study

During the whole study period, total distance covered by the fish did not differ between treatments (Scheirer-Ray-Hare method, $\mathrm{p}=0.87$; family, $\mathrm{p}=0.58$; method $\times$ family, $\mathrm{p}=0.17$; distance covered $=7.5 \pm$ $7.0 \mathrm{~km}$ ). Within each diel cycle, no differences in total distance covered between treatments were found in diurnal (Scheirer-Ray-Hare method, $\mathrm{p}=0.06$; family, $\mathrm{p}=0.25$; method $\times$ family, $\mathrm{p}=0.67$ ) or nocturnal movements (method, $F_{1,26}=0.44, \mathrm{p}=0.51 ;$ family, $F_{1,26}=$ $0.16 \mathrm{p}=0.70$; method $\times$ family, $F_{1,26}=0.94, \mathrm{p}=0.34$ ). As very few fish were detected during twilight (enriched, $\mathrm{n}=11$; traditional, $\mathrm{n}=8$ ), data were only compared by rearing method and no differences were found (MW $U=38, \mathrm{p}=0.66$ ). However, for all fish the distance covered was significantly different between night and day (MW $U=282, \mathrm{p}<0.01$; night vs. twilight, $U=112, \mathrm{p}<0.01$; day vs. twilight, $U=365$, $\mathrm{p}=0.02)$; considerably higher during night hours $(7.9$ $\pm 5.2 \mathrm{~km})$ than during day $(2.5 \pm 3.1 \mathrm{~km})$ and twilight $(4.0 \pm 2.2 \mathrm{~km})$ (Fig. 3). Overall fish movements also revealed that larger fish traveled longer distances for both enriched-reared families (Spearman, C1, $\mathrm{r}=$ $0.57, \mathrm{p}<0.01 ; \mathrm{C} 2, \mathrm{r}=0.66, \mathrm{p}<0.01 ; 7.9 \pm 7.8 \mathrm{~km})$, but this relationship was not found for the fish reared using the traditional method (Spearman, $\mathrm{C} 1, \mathrm{r}=-0.03$, $\mathrm{p}=0.94 ; \mathrm{C} 2, \mathrm{r}=0.29, \mathrm{p}=0.33 ; 6.9 \pm 6.0 \mathrm{~km}$ ) (Fig. 4).

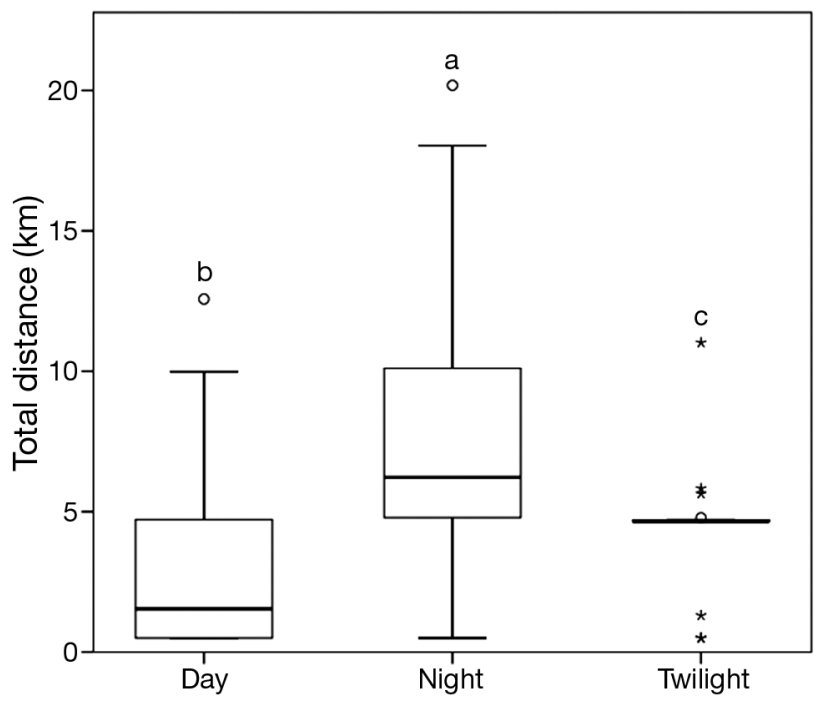

Fig. 3. Total distance covered for 3 mo old European sturgeons stocked in the wild according to the time of day during the whole study period ( $21 \mathrm{~d})$. Boxes: 1st and 3rd quartiles; line: median; whiskers: SD; circles: outliers; asterisks: extreme outliers in a diel period; different letters indicate significant differences
According to the individual trajectory analysis (Fig. 5), fish moved mainly during the first $3 \mathrm{~d}$ after stocking, i.e. $85.7 \%$ of the whole distance covered on average, and they seemed to settle after those $3 \mathrm{~d}$ as few movements were recorded later on.

\section{Initial $3 \mathrm{~d}$ period and remaining days}

During the $3 \mathrm{~d}$ period after release, fish of the different treatments did not differ in total distance moved (Scheirer-Ray-Hare method, $\mathrm{p}=0.54$; family, $\mathrm{p}=0.45$, method $\times$ family, $\mathrm{p}=0.12 ; 6.4 \pm 6.7 \mathrm{~km}$ ). However, during the day, enriched-reared fish were less active than traditionally-reared fish, and fish belonging to family $\mathrm{C} 1$ were less active compared to those belonging to $\mathrm{C} 2$ (Scheirer-Ray-Hare method, $\mathrm{p}<0.01$; family, $\mathrm{p}=0.01$, method $\times$ family, $\mathrm{p}=0.62$ ) (Fig. 6). Movements during the night did not differ between treatments (Scheirer-Ray-Hare method, $\mathrm{p}=0.82$; family, $\mathrm{p}=0.74$, method $\times$ family, $\mathrm{p}=0.66$; distance covered $=7.9 \pm 5.2 \mathrm{~km}$ ). At twilight, movements were scarce and involved few fish (enriched, $\mathrm{n}=11$; traditional, $\mathrm{n}=8$ ) and no differences were found between rearing methods (MW $U=38, \mathrm{p}=0.66$; distance covered $=4 \pm 2.2$ $\mathrm{km})$. When comparing distances moved on the remaining days after the initial $3 \mathrm{~d}$ post-stocking

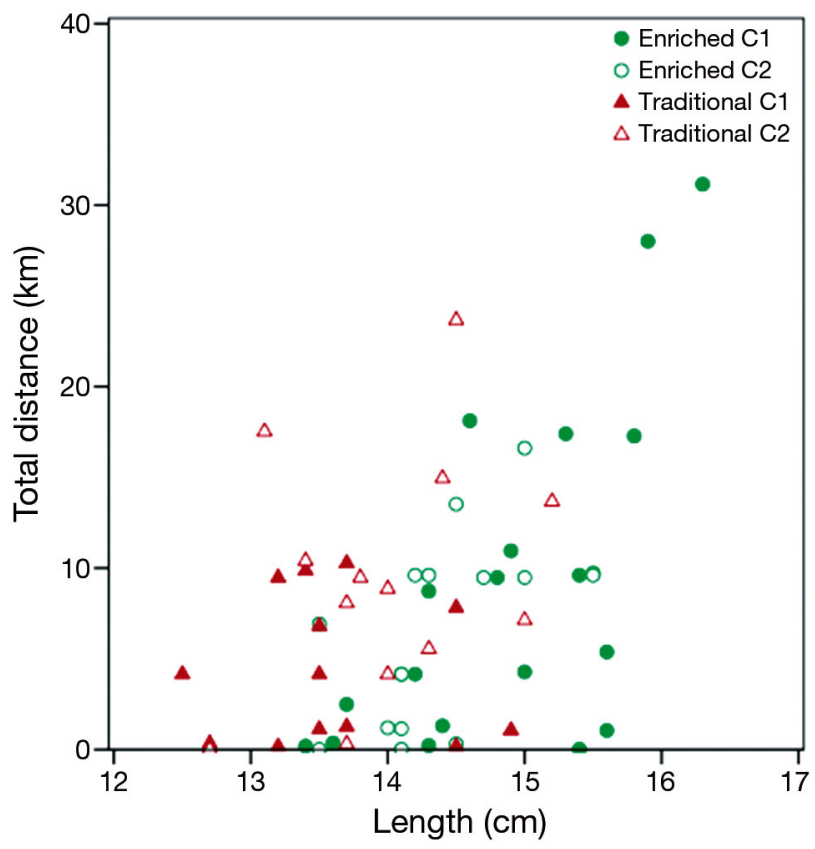

Fig. 4. Total distance covered (21 d) according to fish length for 3 mo old European sturgeons from 2 rearing methods (enriched and traditional) and 2 families ( $\mathrm{C} 1$ and $\mathrm{C} 2$ ), stocked in the wild 

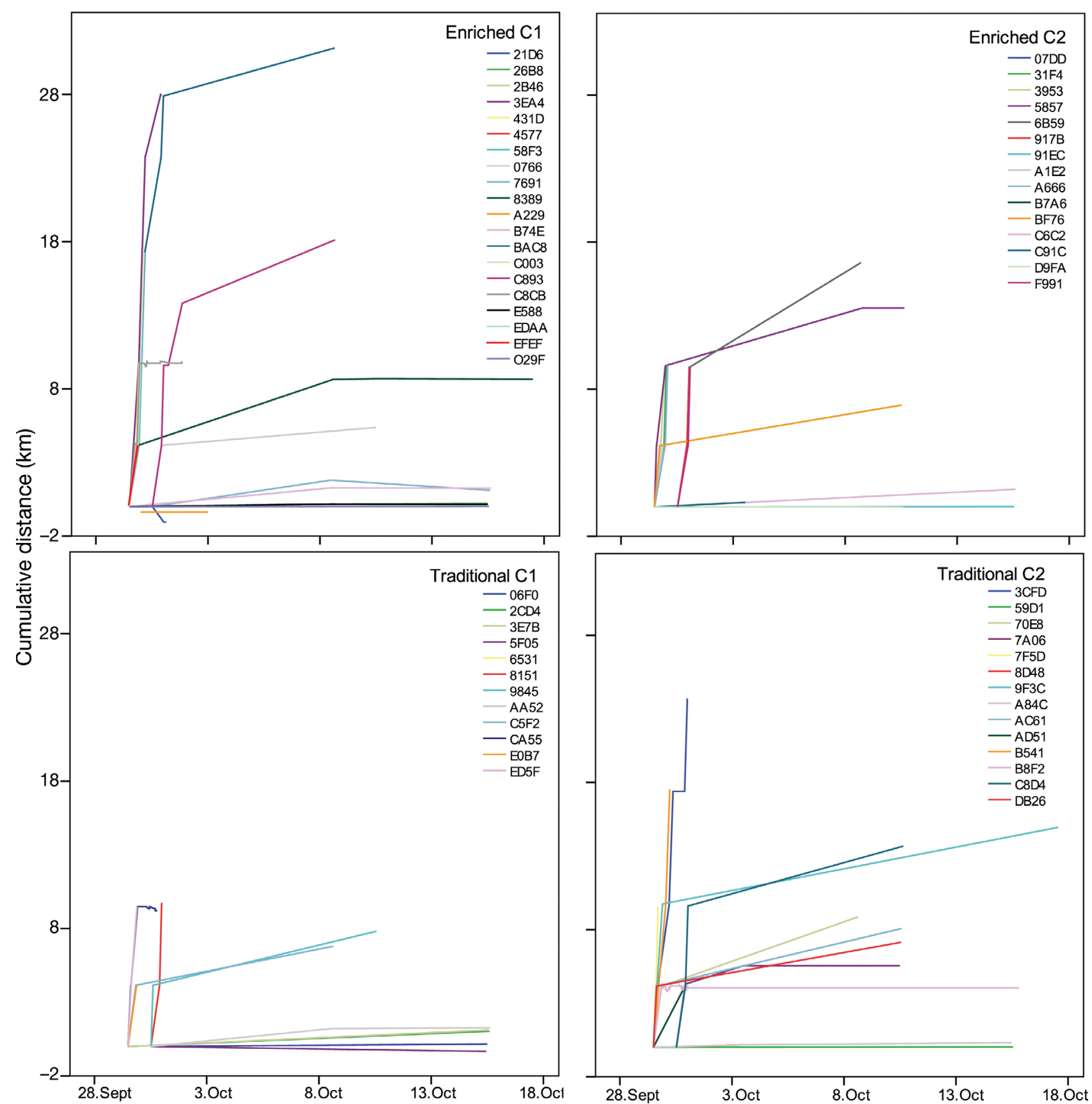

Fig. 5. Individual movement trajectories of 3 mo old European sturgeons belonging to 2 families (C1 and C2) and reared in 2 different environments (traditional and enriched). Fish were acoustically tagged, stocked in the Dordogne River and tracked for $21 \mathrm{~d}$. In each panel, the $y$-axis represents the cumulative distance from the release site, the $x$-axis represents tracked days (date), and each color corresponds to 1 individual

period, we did not find any differences between rearing treatments (Scheirer-Ray-Hare method, $\mathrm{p}=$ 0.79 ; family, $\mathrm{p}=0.72$, method $\times$ family, $\mathrm{p}=0.74$ ) during daylight (Scheirer-Ray-Hare method, $\mathrm{p}=$ 0.89 ; family, $\mathrm{p}=1.00$; method $\times$ family, $\mathrm{p}=0.59$ ); analyses on night and twilight movements were not done due to insufficient data.

\section{DISCUSSION}

For European sturgeon, it is believed that the last natural reproductions in the Gironde occurred in 1988 and 1994 (Lochet et al. 2004). Therefore, wildborn young-of-the-year (YOY) individuals do not currently exist in the watershed. Fish in this study 


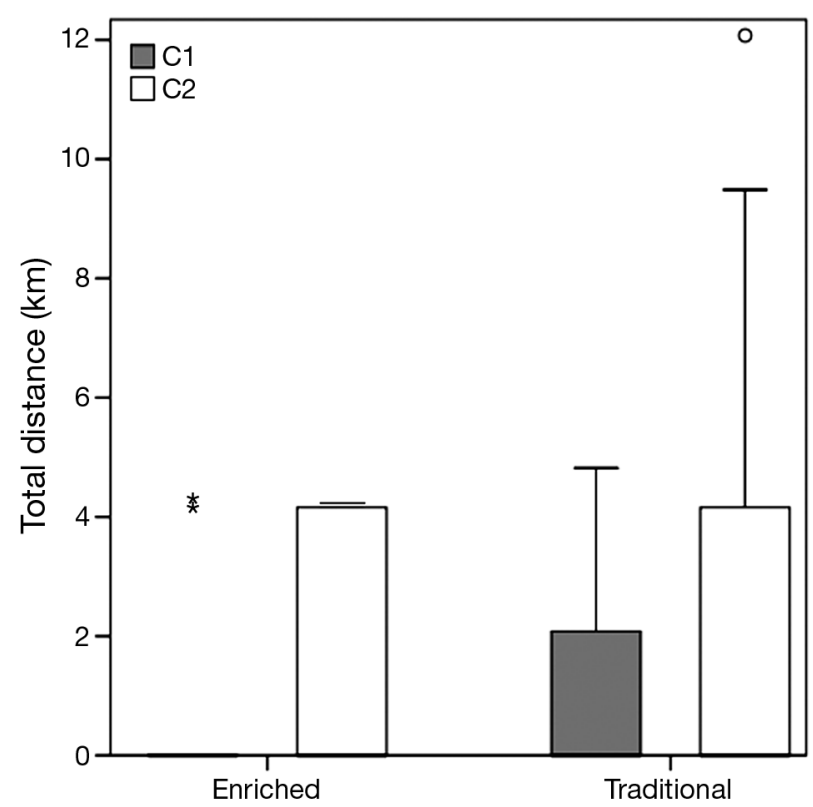

Fig. 6. Total distance (mean $\pm \mathrm{SD}$ ) covered by 3 mo old European sturgeons during the day for the first $3 \mathrm{~d}$ after release. Fish belong to 2 families ( $\mathrm{C} 1$ and $\mathrm{C} 2$ ) and were reared in 2 different environments (traditional and enriched). Enrichedreared fish were less active than traditionally-reared fish, and fish belonging to family $\mathrm{C} 1$ were less active compared to those belonging to $\mathrm{C} 2$. Circle: outlier; asterisks: extreme values

represent the youngest European sturgeon (3 mo old) ever tracked, and thus, our study revealed for the first time the distribution and activity patterns in this age class. The fish in this study are also the smallest of all sturgeon species (12.0 to $16.3 \mathrm{~cm}$ TL) to have been tagged and monitored in the wild to date. These results are important for providing basic knowledge of post-stocking behavior of juvenile sturgeon in freshwater environments. Ours is the first study to consider rearing practices as an explanation of fish fate, and thus the results can help design stocking programs.

\section{Survival estimates}

In this study, data were obtained from $69.3 \%$ of the fish released, and this value was used as a proxy for survival, as all fish were stocked and monitored during the same period of time (Heisey \& Fuller 1985, Jordan et al. 2006, Acolas et al. 2012). The overall survival rate in this study (69.3\%) is acceptable given the estimates from other studies on YOY hatchery-reared sturgeons: $40 \%$ (Crossman et al. 2009) and 5 to $15 \%$ (Crossman et al. 2011) in lake sturgeon Acipenser ful- vescens released at 6 and 2 to 4 mo old respectively, and $87 \%$ in European sturgeon released at 9 to 12 mo old (Acolas et al. 2012). Nevertheless, monitoring duration and fish age varied among those studies and thus an accurate comparison is not possible. Of the 88 fish released, $27(30.7 \%)$ were never detected and one was found upstream, which is suspicious considering the swimming capacity of such small individuals. Although tag malfunction could not be discounted for the fish that were never detected, it is probable that predation was the main reason for fish disappearance or rapid upstream movement as cormorants Phalacrocorax carbo and herons Ardea spp. are commonly present along the river bank as well as larger fish such as the European catfish Silurus glanis. Many authors have confirmed that predation is the main cause of mortality for stocked fish after release $(27 \%$ in largemouth bass, Buckmeier et al. 2005; 46\% in Florida bass, Thompson et al. 2016; $65 \%$ in sea trout, Dieperink et al. 2001) and that it occurs on the days immediately following release (Howell 1994, Svåsand et al. 1998, Blaxter 2000).

In our study, survival of both families under enriched rearing (90.9 and 68.2\%) and traditional C2 $(66.7 \%)$ had higher survival when compared with traditional C1 (52.2\%). Fish size is an important factor influencing predation - smaller fish are at greater risk than larger ones (Dieperink et al. 2001, Juanes et al. 2002) — and traditionally-reared C1 fish were significantly the smallest among all treatments. However, we demonstrated in our study that fish size was not linked to the survival proxy and there is the possibility that low survival in this treatment is better explained by rearing condition effects (Carrera-García et al. 2016). These results would be congruent with studies done on YOY lake sturgeon, where 3 mo old fish had fewer recapture rates when reared traditionally than under a more enriched approach (ca. 2 to 4 fold higher) (Crossman et al. 2011). Nevertheless, there were no differences due to rearing for 4 and 6 mo old fish, suggesting that the influence of rearing may decrease with fish age (Crossman et al. 2009, 2011). In addition, there are other studies where improved post-release survival has been obtained using more enriched rearing approaches: $3.5 \%$ higher in common snook Centropomus undecimalis (Brennan et al. 2006) and 6.4 and 19\% higher in Atlantic salmon Salmo salar (Hyvärinen et al. 2013, Roberts et al. 2014). The enriched rearing approaches would allow the fish to develop morphological, behavioral and cognitive traits that are necessary to respond adequately to wild environments, which would consequently aid survival (Braithwaite 
\& Salvanes 2005, Kotrschal \& Taborsky 2010, Roberts et al. 2014).

\section{European sturgeon habitat}

The fish in this study were encountered in areas of $3.3 \mathrm{~m}$ mean depth (1.4 to $6.2 \mathrm{~m}$ ) and $0.09 \mathrm{~m} \mathrm{~s}^{-1}$ mean water current velocity $\left(0.004\right.$ to $\left.0.4 \mathrm{~m} \mathrm{~s}^{-1}\right)$. The only data available for YOY $A$. sturio in the wild are beam trawl sampling captures of 2 individuals of about $10 \mathrm{~cm}$, between 9 and $20 \mathrm{~km}$ downstream of their release site in low water velocity $\left(<0.25 \mathrm{~m} \mathrm{~s}^{-1}\right)$ and fine substrate habitat (Acolas et al. 2011c). Previous studies on swimming performance of Dabry's sturgeon A. dabryanus and Amur sturgeon A. schrenckii of similar size to those in our study had a mean critical swimming speed $\left(U_{\text {crit }}\right.$, relationship between exercise intensity and duration) of 0.36 to $0.48 \mathrm{~m} \mathrm{~s}^{-1}$ depending on whether they were previously trained or not (Cai et al. 2013, Du et al. 2014). In A. sturio, a preliminary test on $9 \mathrm{~cm}$ juveniles highlighted that fish reared under traditional conditions were able to cope with a $0.2 \mathrm{~m} \mathrm{~s}^{-1}$ current only after $2 \mathrm{~d}$ of acclimation (Charles et al. 2009). Concerning depth, no data are available for 3 mo old A. sturio, but for 9 mo old fish, Acolas et al. (2017) highlighted a preference for 5 to $8 \mathrm{~m}$ depth ( 2 to $5 \mathrm{~m}$ in tidal areas). Fredrich et al. (2008) reported that 9 mo old Atlantic sturgeons were mainly located in zones of 3 to $5 \mathrm{~m}$ depth in the Notec and Drawa rivers, Poland.

\section{Diel rhythm in freshwater}

Our study revealed that YOY European sturgeons are mainly nocturnal while in riverine systems, moving downstream during night hours. This is consistent with a previous study of this species under controlled conditions (Charles et al. 2009), and with observations of the closely related Atlantic sturgeon A. oxyrinchus (Fredrich et al. 2008) and Gulf of Mexico sturgeon $A$. oxyrinchus desotoi (Kynard \& Parker 2004), as well as for other less related acipenserids such as lake sturgeon A. fulvescens (Benson et al. 2005) and green sturgeon A. medirostris (Kynard et al. 2005). In the tidal area and the saline estuary, Acolas et al. (2012) found no differential diel movements in 10 mo old European sturgeon. It is possible that this is because the clear water in the river could expose them to predators during the day, whereas diel behavior is less important in the estuary where the channel is deeper and the water is turbid. Thus, increased activity at night in most acipenserid species could be considered as an evolutionary response to predation while in freshwater habitats (Wishingrad et al. 2015).

\section{Movement orientation and early migration tactics}

We also observed that orientation of the European sturgeon was mostly directed downstream. Such patterns (mainly downstream migration with occasional upstream movements) have also been reported in YOY Atlantic sturgeon (Kynard \& Horgan 2002, Fredrich et al. 2008, Kapusta et al. 2011). During the whole study, $82 \%$ of the fish did not move more than $13.5 \mathrm{~km}$ downstream from the release site. Also, most movements occurred during the $3 \mathrm{~d}$ immediately after release, after which the fish apparently settled. We cannot exclude a linkage between these movements and stress, as suggested for thinlip mullet Liza ramada which, when caught, tagged and released displayed a quick downstream movement before coming back to their capture site (Le Pichon et al. 2015). However, our fish were tagged at the hatchery, and if the downstream movement were a sign of stress it would be more likely linked to the release in an unknown environment. Moreover, the downstream movement was not very far from the release site, suggesting that immediately following release, stocked sturgeons move to find suitable areas. An experimental study done by Kynard \& Horgan (2002) on Atlantic sturgeons pointed out that free embryos hid, then started migrating at $8 \mathrm{dph}$ and ceased migration at $19 \mathrm{dph}$. Later on, fish were reported to swim actively but did not resume migration during the ca. 4 mo observation period. This could suggest that after release, young European sturgeon reach favorable patches, stay in them and later continue travelling downstream. This behavior has also been reported in 9 mo old Atlantic sturgeon (Fredrich et al. 2008) and European sturgeon (Acolas et al. 2012).

By the end of our study, 95.1\% of the fish (aged 4 mo old) had settled in freshwater and only $4.9 \%$ reached the tide-influenced zone; no fish reached the oligohaline zone of the estuary. Development of salinity tolerance has not been studied in YOY European sturgeons. Nevertheless, all anadromous sturgeon species must develop such tolerance (Altinok et al. 1998, Bain et al. 2000, Kynard \& Horgan 2002, Allen et al. 2011), which is age-dependent (Magnin 1962, Altinok et al. 1998) and as far as it is known, occurs between 9 and 12 mo old at the earliest (Kynard et al. 2005). Hatin et al. (2007) pointed out that habitat use in Atlantic sturgeon juveniles is controlled by 
salinity and distance to the salt wedge where YOY use freshwater zones only. Furthermore, from previous telemetry studies, we know that 10 mo old stocked European sturgeons reached the saline estuary soon after release (Acolas et al. 2012, 2017). Thus, we suspect that the downstream migration towards saline waters occurs between 4 and 10 mo of age for stocked European sturgeons.

\section{Rearing influence on fish behavior}

Our study revealed behavioral differences related to fish family and rearing methodology for the first days after release. Traditionally-reared fish were more active during the day than enriched-reared fish during the first $3 \mathrm{~d}$ after release. As the former fish were maintained under complete darkness, their circadian clock probably did not match the outdoor lightdark cycle. In the long run, fish reared under traditional rearing would acquire a diel rhythm because the environment would induce the synchronization of this rhythm (Reebs 2002, Zhdanova \& Reebs 2006). However, it takes some time for the fish to adjust and, during entrainment, those fish may be more at risk from predators than the enriched-reared fish, affecting their survival during the first days of release. For example, these fish could have been more exposed to cormorants, which are diurnal and feed mainly on fish within the size range of those in this study (Kirby et al. 1996). Moreover, Carrera-García et al. (2016) highlighted that traditionally-reared fish were lightcolored compared with enriched-reared fish. Fairchild \& Howell (2004) demonstrated that the unnatural light color and abnormal behavior of hatchery-raised flounders made them more conspicuous to predators, explaining flounders' low survival after stocking.

In our study, the total distance covered did not significantly differ according to fish rearing treatment; however, the only fish that reached the tidal area were reared under enriched conditions. We suggest that the effects of rearing condition on exploratory behavior, as reported by Carrera-García et al. (2016), may have resulted in these individuals traveling farther. Moreover, a correlation between fish size and distance moved was found only for enriched-reared fish. As these fish were reared under water-current conditions (Carrera-García et al. 2016), they probably had better swimming performance, which is often positively correlated with size (Wardle 1977). Traditionally-reared fish were not trained to cope with water currents and thus whatever their size, their swimming capacity was probably low at release.

\section{CONCLUSIONS}

Our results reveal, for the first time, the behavior and survival of young European sturgeon in the wild, improving our knowledge of their diel activity, movements and survival just after stocking. Our results also highlight that the first $3 \mathrm{~d}$ after stocking seem to be critical for YOY European sturgeons. We suggest that rearing conditions of YOY sturgeons should be considered in stocking for conservation programs because these can influence diel rhythm and early survival, at least during the first days after release.

Acknowledgements: This study was funded in 2014 within the French national action plan in favor of European sturgeon restoration by the water agency Adour Garonne, Aquitaine region, General Council Gironde and the regional direction of the environment Ministry. A PhD grant was allocated to E.C.G. by the National Office of Water and Aquatic Environment (ONEMA) and the National Research Institute of Science and Technology for Environment and Agriculture (Irstea). We thank the personnel of Irstea Saint Seurin experimentation station for their contribution in the fish rearing, Philippe Vignac, a professional fisherman, for his help with field work and Maud Pierre (Irstea) for her advice on data processing. This study was carried out in an approved experimental hatchery facility by the French Department of Agriculture (authorization A33-478-001) and followed the standards of the National Ethic Committee of Animal Use for Scientific Purposes (authorization 01738.01).

\section{LITERATURE CITED}

Acolas ML, Castelnaud G, Lepage M, Rochard E (2011a) Biological cycles and migrations of Acipenser sturio. In: Williot P, Rochard E, Desse-Berset N, Kirschbaum F, Gessner J (eds) Biology and conservation of the Atlantic European sturgeon Acipenser sturio L. 1758: the reunion of the European and Atlantic sturgeons. Springer-Verlag, Berlin, p 147-152

Acolas ML, Gessner J, Rochard E (2011b) Population conservation requires improved understanding of in situ life histories. In: Williot $\mathrm{P}$, Rochard E, Desse-Berset $\mathrm{N}$, Kirschbaum F, Gessner J (eds) Biology and conservation of the European sturgeon Acipenser sturio L. 1758: the reunion of the European and Atlantic sturgeons. Springer-Verlag, Berlin, p 585-602

Acolas ML, Roqueplo C, Rouleau E, Rochard E (2011c) Post release monitoring techniques. In: Williot $\mathrm{P}$, Rochard $\mathrm{E}$, Desse-Berset N, Kirschbaum F, Gessner J (eds) Biology and conservation of the European sturgeon Acipenser sturio L. 1758: the reunion of the European and Atlantic sturgeons. Springer-Verlag, Berlin, p 407-415

Acolas ML, Rochard E, Le Pichon C, Rouleau E (2012) Downstream migration patterns of one-year-old hatchery-reared European sturgeon (Acipenser sturio). J Exp Mar Biol Ecol 430-431:68-77

Acolas ML, Le Pichon C, Rochard E (2017) Spring habitat use by stocked one year old European sturgeon Acipenser sturio in the freshwater-oligohaline area of the Gironde estuary. Estuar Coast Shelf Sci 196:58-69 
Agafonkin V (2009) SunCalc. http://suncalc.net/\#/43.3,5.4, 12/2014.09.01/12:56 (accessed 1 Sept 2014)

Allen PJ, McEnroe M, Forostyan T, Cole S, Nicholl MM, Hodge B, Cech JJ (2011) Ontogeny of salinity tolerance and evidence for seawater-entry preparation in juvenile green sturgeon, Acipenser medirostris. J Comp Physiol B 181:1045-1062

Altinok I, Galli SM, Chapman FA (1998) Ionic and osmotic regulation capabilities of juvenile Gulf of Mexico sturgeon, Acipenser oxyrinchus desotoi. Comp Biochem Physiol Part A Physiol 120:609-616

Arlati G, Poliakova L (2009) Restoration of Adriatic sturgeon (Acipenser naccarii) in Italy: situation and perspectives. In: Carmona R, Domezain A, García-Gallego M, Hernando J, Rodríguez F, Ruiz-Rejón M (eds) Biology, conservation and sustainable development of sturgeons. Springer, Dordrecht, p 237-246

Bain M, Haley N, Peterson D, Waldman J, Arend K (2000) Harvest and habitats of Atlantic sturgeon Acipenser oxyrinchus Mitchill, 1815 in the Hudson River estuary: lessons for sturgeon conservation. Bol Inst Esp Oceanogr 16:43-54

Bégout ML, Bau F, Acou A, Acolas ML (2016) Methodologies for investigating diadromous fish movements: conventional, PIT, acoustic and radio tagging and tracking. In: Morais P, Daverat F (eds) An introduction to fish migration. CRC Press, Boca Raton, FL, p 214-250

Benson AC, Sutton TM, Elliott RF, Meronek TG (2005) Seasonal movement patterns and habitat preferences of age0 lake sturgeon in the lower Peshtigo River, Wisconsin. Trans Am Fish Soc 134:1400-1409

Blaxter JHS (2000) The enhancement of marine fish stocks. Adv Mar Biol 38:2-54

Braithwaite VA, Salvanes AGV (2005) Environmental variability in the early rearing environment generates behaviourally flexible cod: implications for rehabilitating wild populations. Proc R Soc B 272:1107-1113

Brennan NP, Darcy MC, Leber KM (2006) Predator-free enclosures improve post-release survival of stocked common snook. J Exp Mar Biol Ecol 335:302-311

Brosse L (2003) Caractérisation des habitats des juvéniles d'esturgeon européen, Acipenser sturio, dans l'estuaire de la Gironde. PhD dissertation, Université Paul Sabatié, Toulouse

Buckmeier DL, Betsill RK, Schlechte JW (2005) Initial predation of stocked fingerling largemouth bass in a Texas reservoir and implications for improving stocking efficiency. N Am J Fish Manage 25:652-659

Cai L, Taupier R, Johnson D, Tu Z, Liu G, Huang Y (2013) Swimming capability and swimming behavior of juvenile Acipenser schrenckii. J Exp Zool A Ecol Genet Physiol 319:149-155

Campton DE (1995) Genetic effects of hatchery fish on wild populations of Pacific salmon and steelhead: What do we really know? Am Fish Soc Symp 15:337-353

* Carrera-García E, Rochard E, Acolas ML (2016) European sturgeon (Acipenser sturio L.) young of the year performance in different rearing environments - study within a stocking program. Environ Biol Fishes 99:887-901

* Carrera-García E, Kordek J, Gesset C, Jacobs L, Acolas ML (2017) Tracking juvenile sturgeon in the wild: miniature tag effects assessment in a laboratory study on Siberian sturgeon (Acipenser baerii). Fish Res 186:337-344

Castelnaud G, Rochard E, Jatteau P, Lepage M (1991) Données actuelles sur la biologie d'Acipenser sturio dans l'estuaire de la Gironde. In: Williot P (ed) Acipenser. Cemagref Publication, Antony, p 251-275

Charles K, Roqueplo C, Jatteau P (2009) Action n9: identification expérimentale des préférences d'habitat des jeunes stades. In: Rochard E (ed) Programme de recherche et de conservation de l'esturgeon européen Acipenser sturio; bilan scientifique et technique 2008. Cemagref de Bordeaux, étude ${ }^{\circ} 133$, p 54-64

Chèvre P, Saint-Sevin J, Mercier D, Jacobs L, Williot P (2011) Recent progress in larval rearing of the European sturgeon, Acipenser sturio. In: Williot P, Rochard E, Desse-Berset N, Kirschbaum F, Gessner J (eds) Biology and conservation of the European sturgeon Acipenser sturio L. 1758: the reunion of the European and Atlantic sturgeons. Springer-Verlag, Berlin, p 449-454

Cooke SJ, Hinch SG, Wikelski M, Andrews RD, Kuchel LJ, Wolcott TG, Butler PJ (2004) Biotelemetry: a mechanistic approach to ecology. Trends Ecol Evol 19:334-343

IBM Analytics (2013) IBM SPSS Statistics version 22.0. IBM Corporation, Armonk, NY

C Crossman JA, Forsythe PS, Baker EA, Scribner KT (2009) Overwinter survival of stocked age-0 lake sturgeon. J Appl Ichthyol 25:516-521

Crossman JA, Forsythe PS, Scribner KT, Baker EA (2011) Hatchery rearing environment and age affect survival and movements of stocked juvenile lake sturgeon. Fish Manag Ecol 18:132-144

Dieperink C, Pedersen S, Pedersen MI (2001) Estuarine predation on radiotagged wild and domesticated sea trout (Salmo trutta L.) smolts. Ecol Freshwat Fish 10:177-183

* Du H, Wei QW, Xie X, Shi LL, Wu JM, Qiao XM, Liu ZG (2014) Improving swimming capacity of juvenile Dabry's sturgeon, (Acipenser dabryanus Dume'ril, 1869) in current-enriched culture tanks. J Appl Ichthyol 30: 1445-1450

* Dudgeon D, Arthington AH, Gessner MO, Kawabata ZI and others (2006) Freshwater biodiversity: importance, threats, status and conservation challenges. Biol Rev Camb Philos Soc 81:163-182

* Eder BL, Steffensen KD, Haas JD, Adams JD (2015) Shortterm survival and dispersal of hatchery-reared juvenile pallid sturgeon stocked in the channelized Missouri River. J Appl Ichthyol 31:991-996

ESRI (2013) ArcGis. ESRI, Redlands, CA

F Fairchild EA, Howell WH (2004) Factors affecting the postrelease survival of cultured juvenile Pseudopleuronectes americanus. J Fish Biol 65:69-87

Fredrich F, Kapusta A, Ebert M, Duda A, Gessner J (2008) Migratory behavior of young sturgeon, Acipenser oxyrinchus Mitchill, in the Oder River drainage. Preliminary results of a radio telemetric study in the Drawa River, Poland. Arch Pol Fisheries 16:105-117

Gitzen R, Keller B, Miller M, Goetz S and others (2016) Effective and purposeful monitoring of species reintroductions. In: Jachowski DS, Millspaugh JJ, Angermeier PL, Slotow R (eds) Reintroduction of fish and wildlife populations. University of California Press, Okland, CA, p 283-318

Hatin D, Munro J, Caron F, Simons R (2007) Movements, home range size, and habitat use and selection of early juvenile Atlantic sturgeon in the St. Lawrence estuarine transition zone. Am Fish Soc Symp 56:129-155

* Heisey DM, Fuller TK (1985) Evaluation of survival and cause-specific mortality rates using telemetry data. J Wildl Manage 49:668-674 
Howell B (1994) Fitness of hatchery-reared fish for survival in the sea. Aquacult Fish Manage 25:3-17

HHYDRO (2015) Banque HYDRO. www.hydro.eaufrance.fr/ (accessed 15 Nov 2015)

*Hyvärinen P, Rodewald P, Bradford M (2013) Enriched rearing improves survival of hatchery-reared Atlantic salmon smolts during migration in the River Tornionjoki. Can J Fish Aquat Sci 70:1386-1395

* IUCN (2015) The IUCN Red List of Threatened Species. www.iucnredlist.org (accessed 20 Jan 2016)

Jager HI (2005) Genetic and demographic implications of aquaculture in white sturgeon (Acipenser transmontanus) conservation. Can J Fish Aquat Sci 62:1733-1745

* Jego S, Gazeau C, Jatteau P, Elie P, Rochard E (2002) Les frayères potentielles de l'esturgeon européen Acipenser sturio L. 1758 dans le bassin Garonne-Dordogne. Méthodes d'investigation, état actuel et perspectives. Bull Fr Peche Piscicult 365-366:487-505

Johnsson JI, Brockmark S, Näslund J (2014) Environmental effects on behavioural development consequences for fitness of captive-reared fishes in the wild. J Fish Biol 85: 1946-1971

Jordan GR, Klumb RA, Wanner GA, Stancill WJ (2006) Poststocking movements and habitat use of hatchery-reared juvenile pallid sturgeon in the Missouri River below Fort Randall Dam, South Dakota and Nebraska. Trans Am Fish Soc 135:1499-1511

Juanes F, Buckel JA, Scharf FS (2002) Feeding ecology of piscivorous fishes. In: Hart PJB, Reynolds JD (eds) Handbook of fish biology and fisheries, Vol 1: Fish biology. Blackwell Publishing, Oxford, p 267-283

Kapusta A, Morzuch J, Kolman R (2011) Movement and habitat use of juvenile Atlantic sturgeon in the Wisłoka River (southern Poland). Arch Pol Fisheries 19:95-103

* Kirby JS, Holmes JS, Sellers RM (1996) Cormorants Phalacrocorax carbo as fish predators: an appraisal of their conservation and management in Great Britain. Biol Conserv 75:191-199

Kotrschal A, Taborsky B (2010) Environmental change enhances cognitive abilities in fish. PLOS BIOL 8: e1000351

Kynard B, Horgan M (2002) Ontogenetic behavior and migration of Atlantic sturgeon, Acipenser oxyrinchus oxyrinchus, and shortnose sturgeon, A. brevirostrum, with notes on social behavior. Environ Biol Fishes 63: $137-150$

Kynard B, Parker E (2004) Ontogenetic behavior and migration of Gulf of Mexico sturgeon, Acipenser oxyrinchus desotoi, with notes on body color and development. Environ Biol Fishes 70:43-55

Kynard B, Parker E, Parker T (2005) Behavior of early life intervals of Klamath River green sturgeon, Acipenser medirostris, with a note on body color. Environ Biol Fishes 72:85-97

Lassalle G, Béguer M, Rochard E (2011) An overview on geographical distribution from past descriptions. In: Williot P, Rochard E, Desse-Berset N, Kirschbaum F, Gessner J (eds) Biology and conservation of the European sturgeon Acipenser sturio L. 1758: the reunion of the European and Atlantic sturgeons. Springer-Verlag, Berlin, p 81-90

Le Pichon C, Gorges G, Faure T, Boussard H (2006) Anaqualand 2.0: modelling connectivity in riverscapes. Cemagref, Antony

* Le Pichon C, Coustillas J, Rochard E (2015) Using a multi- criteria approach to assess post-release recovery periods in behavioural studies: study of a fish telemetry project in the Seine Estuary. Anim Biotelem 3:30

Lochet A, Lambert P, Lepage M, Rochard E (2004) Croissance de juvéniles d'esturgeons européens Acipenser sturio (Acipenseridae) sauvages et issus d'alevinage, durant leur séjour dans l'estuaire de la Gironde (France). Cybium 28:91-98

* Lucas MC, Baras E (2000) Methods for studying spatial behaviour of freshwater fishes in the natural environment. Fish Fish 1:283-316

Magnin E (1962) Recherches sur la systématique de la biologie des Acipenséridés. Annales de la station centrale d'hydrobiologie appliquée 9:7-242

McMichael GA, Eppard MB, Carlson TJ, Carter JA and others (2010) The juvenile salmon acoustic telemetry system: a new tool. Fisheries (Bethesda, Md) 35:9-22

MEDDTL (Ministère de l'écologie du développement durable des transports et du logement) (2011) Plan national d'actions en faveur de l'esturgeon européen Acipenser sturio: 2011-2015. MEDDTL, Paris

*Neufeld MD, Rust PJ (2009) Using passive sonic telemetry methods to evaluate dispersal and subsequent movements of hatchery-reared white sturgeon in the Kootenay River. J Appl Ichthyol 25:27-33

Nichols JD, Armstrong DP (2012) Monitoring for reintroductions. In: Ewen JG, Armstrong DP, Parker KA, Seddon PJ (eds) Reintroduction biology: integrating science and management. Wiley-Blackwell, Oxford, p 223-255

* Parkyn DC, Murie DJ, Colle DE, Holloway JD (2006) Postrelease survival and riverine movements of Gulf of Mexico sturgeon (Acipenser oxyrinchus desotoi Acipenseriformes) following induced spawning. J Appl Ichthyol 22: $1-7$

R Core Team (2013) R: a language and environment for statistical computing. R Foundation for Statistical Computing, Vienna

Reading RP, Miller B, Shepherdson D (2013) The value of enrichment to reintroduction success. Zoo Biol 32:332-341

* Reebs SG (2002) Plasticity of diel and circadian activity rhythms in fishes. Rev Fish Biol Fish 12:349-371

Roberts LJ, Taylor J, Gough PJ, Forman DW, Garcia de Leaniz C (2014) Silver spoons in the rough: Can environmental enrichment improve survival of hatchery Atlantic salmon Salmo salar in the wild? J Fish Biol 85:1972-1991

* Rochard E, Lepage M, Dumont P, Tremblay S, Gazeau C (2001) Downstream migration of juvenile European sturgeon Acipenser sturio L. in the Gironde estuary. Estuaries 24:108-115

* Rudd MB, Ahrens RNM, Pine WE, Bolden SK (2014) Empirical, spatially explicit natural mortality and movement rate estimates for the threatened Gulf sturgeon (Acipenser oxyrinchus desotoi). Can J Fish Aquat Sci 71: 1407-1417

Salvanes AG, Braithwaite V (2006) The need to understand the behaviour of fish reared for mariculture or restocking. ICES J Mar Sci 63:345-354

Secor DH, Niklitschek EJ, Stevenson JT, Gunderson TE and others (2000) Dispersal and growth of yearling Atlantic sturgeon, Acipenser oxyrinchus, released into Chesapeake Bay. Fish Bull 98:800-810

Secor DH, Anders PJ, Van Winkle W, Dixon DA (2002) Can we study sturgeons to extinction? What we do and don't know about the conservation of North American sturgeons. Am Fish Soc Symp 28:3-10 
Susnik S, Berrebi P, Dovc P, Hansen MM, Snoj A (2004) Genetic introgression between wild and stocked salmonids and the prospects for using molecular markers in population rehabilitation: the case of the Adriatic grayling (Thymallus thymallus L. 1785). Heredity 93:273-282

Svåsand T, Skilbrei OT, Van Der Meeren GI, Holm M (1998) Review of morphological and behavioural differences between reared and wild individuals: implications for sea-ranching of Atlantic salmon, Salmo salar L., Atlantic cod, Gadus morhua L., and European lobster, Homarus gammarus L. Fish Manag Ecol 5:473-490

Thompson BC, Porak WF, Leone EH, Allen MS (2016) Using radiotelemetry to compare the initial behavior and mortality of hatchery-reared and wild juvenile Florida bass. Trans Am Fish Soc 145:374-385

Waldman JR, Wirgin II (1998) Status and restoration options for Atlantic sturgeon in North America. Conserv Biol 12: 631-638

Wardle C (1977) Effects of size on the swimming speeds of fish. In: Pedley TJ (ed) Scale effects in animal locomotion. Academic Press, New York, NY, p 299-313

Williot P, Brun R, Rouault T, Pelard M, Mercier D (2005) Attempts at larval rearing of the endangered western European sturgeon, Acipenser sturio L. (Acipensesri-

Editorial responsibility: Eduardo Martins, Vancouver, British Columbia, Canada dae), in France. Cybium 29:381-387

Williot P, Rochard E, Rouault T, Kirschbaum F (2009) Acipenser sturio recovery research actions in France. In: Carmona R, Domezain A, García-Gallego M, Hernando J, Rodríguez F, Ruiz-Rejón M (eds) Biology, conservation and sustainable development of sturgeons. Springer, Dordrecht, p 247-263

Wishingrad V, Musgrove Annessa B, Chivers Douglas P, Ferrari Maud CO (2015) Risk in a changing world: environmental cues drive anti-predator behaviour in lake sturgeon (Acipenser fulvescens) in the absence of predators. Behaviour 152:635-652

Yokota M, Harada Y, Iizuka M (2003) Genetic drift in a hatchery and the maintenance of genetic diversity in hatchery-wild systems. Fish Sci 69:101-109

Zhdanova I, Reebs S (2006) Circadian rhythms in fish. In: Sloman KA, Wilson RW, Balshine S (eds) Fish physiology, Vol 4: Behaviour and physiology of fish. Academic Press, New York, NY, p 197-238

* Zhu B, Zhou F, Cao H, Shao Z, Zhao N, May B, Chang J (2002) Analysis of genetic variation in the Chinese sturgeon, Acipenser sinensis: estimating the contribution of artificially produced larvae in a wild population. J Appl Ichthyol 18:301-306

Submitted: April 18, 2017; Accepted: August 1, 2017 Proofs received from author(s): September 23, 2017 